\author{
Magdalena GAMRAT \\ ORCID: 0000-0002-4130-0988 \\ Uniwersytet Pedagogiczny im. KEN \\ w Krakowie
}

\title{
Media elektroniczne a czas wolny dzieci w percepcji rodziców
}

\begin{abstract}
Electronic Media and Children's Leisure Time in the Perception of the Parents
Nowadays, more and more children own electronic devices and spend a significant amount of their free time using them during the day. Currently, the Internet offers great opportunities for children - it can be both a source of entertainment and information. Unfortunately, more and more often it can be noticed that children rarely go out to the yard or playground and spend most of their free time in front of a computer or TV screen instead. The scale of this phenomenon is increasing every year as electronic devices have become an integral part of everyone's life, including children.

The conducted research showed that parents spend an average of 2.5 hours a day with their children, during which they most often go for walks, play sports or play board games. It has also been shown that the vast majority of $2^{\text {nd }}$ grade primary school students have their own electronic devices, most often a telephone. According to the research, children's use of phone is unlimited by their parents, can take place at any time of the day, and it is mainly used for entertainment purposes.
\end{abstract}

Keywords: children's leisure time, electronic media

Słowa kluczowe: czas wolny dzieci, media elektroniczne

\section{Wprowadzenie}

W XXI w. nastąpił rozkwit technologii. Na rynku pojawiają się coraz nowsze modele telefonów, laptopów, tabletów itd. Można się również spotkać z nowymi nazwami sprzętów elektronicznych, takimi jak netbook, ultrabook, palmtop i wiele innych. A wszystko po to, aby ludzie mogli na cały czas mieć kontakt ze światem wirtualnym. Media elektroniczne cieszą się dużym zainteresowaniem wśród dorosłych, ale także wśród dzieci. W związku z tym coraz więcej 
dzieci posiada własny sprzęt elektroniczny i spędza z nim dużą ilość czasu wolnego w ciągu dnia. Obecnie internet daje duże możliwości - może być dla dzieci źródłem rozrywki oraz informacji. Mogą one w sieci oglądać bajki, grać w różne gry, ale także wyszukiwać interesujące ich ciekawostki oraz wiadomości, które potrzebne im są do odrobienia zadań domowych. Niestety, coraz częściej można zauważyć, że dzieci rzadziej wychodzą na podwórko czy plac zabaw, a w zamian za to siedzą przed ekranem komputera lub telewizora. Skala tego zjawiska jest $\mathrm{z}$ roku na rok coraz większa, ponieważ urządzenia elektroniczne stają się nieodłączną częścią życia każdego człowieka, także dziecka.

\section{Czas wolny - ujęcie definicyjne}

Czas wolny jest pojęciem bardzo szerokim. Aneta Jegier przedstawia w książce Czas wolny małych dzieci w świecie realnym $i$ wirtualnym najpowszechniejsze definicje. Jedną z nich jest definicja Kazimierza Czajkowskiego, który mówi, że „czas wolny to przedział czasowy, który człowiek spędza bez pracy oraz bez wykonywania czynności dnia codziennego" (za: Jegier (red.), 2016, s. 12). Joffre Dumazedier twierdzi natomiast, że czas wolny „jest zespołem zajęć, którym jednostka oddawać się może z własnej woli bądź dla odpoczynku, bądź dla rozrywki, bądź dla rozwoju swych wiadomości lub bezinteresownego kształcenia się względnie dla swego dobrowolnego uczestnictwa w życiu społecznym, po wyzwoleniu się od obowiązków zawodowych, rodzinnych, społecznych" (za: Czerepaniak-Walczak, 1997, s. 21). Przytoczone definicje trudno odnieść do dzieci, ponieważ dotyczą one czasu wolnego dorosłych. W artykule Czas wolny dzieci we wspótczesnych polskich miastach można znaleźć informację, że „czas wolny dzieci różni się od czasu wolnego dorosłych tym, że objęty jest nadzorem i kontrolą zarówno ze strony osób dorosłych (rodzice, nauczyciele, opiekunowie, animatorzy kultury), jak i przeznaczonych do tego celu instytucji (szkoły, instytucje kultury, jednostki organizujące czas wolny). Mimo nadzoru i kontroli dzieci mają jednak pewną dobrowolność wyboru zajęć w czasie wolnym" (Martyka, 2012, s. 109). Jadwiga Izdebska stworzyła definicję czasu wolnego dzieci, który określiła jako „okres, który pozostaje mu [dziecku] po wypełnieniu obowiązków szkolnych, domowych, czynności organizacyjno-porządkowych, związanych $\mathrm{z}$ zachowaniem zdrowia i higieny, czas, w którym może ono wykonywać czynności według swojego upodobania, związane $z$ wypoczynkiem, rozrywką i zaspokajaniem potrzeb wynikających z własnych zainteresowań” (za: Jegier (red.), 2016, s. 12). Pojęcie czasu wolnego jest jednak subiektywne, ponieważ dana czynność przez jedno dziecko może być uważana za dobrowolną i nieobowiązkową, dla drugiego natomiast będzie to jedno z zajęć koniecznych do wykonania w ciągu dnia, niesprawiające mu żadnej przyjemności (Czerepaniak-Walczak, 
1997). Czas wolny dziecka to też taki okres w ciągu dnia, w którym wykonuje się obowiązki wynikające np. z członkostwa w jakieś grupie, lecz dobrowolnie, bez przymusu (Łobocki, 1994). Czas wolny jest więc dla dziecka czymś przyjemnym. Jest czasem, który upływa mu bez pośpiechu i w którym może podejmować różne interesujące go aktywności, których nie narzuca mu inna osoba.

Dzieci spędzają większość dnia w szkole, gdzie nauczyciele mają dyżur już od godziny 6.30, a po zajęciach właściwych prowadzone są zajęcia w świetlicy, gdzie dzieci czekają, aż odbiorą je rodzice. Przez ten czas pedagodzy zapewniają im opiekę i prowadzą zajęcia zgodne z programami Ministerstwa Edukacji Narodowej, a także zajęcia dodatkowe. W placówkach szkolnych działają różne koła zainteresowań, np.: plastyczne, muzyczne, sportowe, językowe, matematyczne. Dzieci mają możliwość korzystania z tych spotkań pod nadzorem nauczycieli, poszerzania swoich zainteresowań i zdolności pod okiem specjalistów, a przy okazji miło spędzają czas, ponieważ robią, to co lubią. Niestety, w ostatnich latach coraz częściej się zdarza, że czas wolny dzieci nie jest kontrolowany przez rodziców. Dzieci, wróciwszy do domu, mogą robić, co zechcą, a rodzice nie kontrolują, ile czasu spędzają przed telewizorem czy komputerem. Rodzice są zajęci sprzątaniem, gotowaniem lub odpoczynkiem po pracy i zapominają, że dzieci potrzebują ich czasu, uwagi i miłości.

\section{Rodzina a czas wolny}

Postawa rodziny jest ważna podczas kształtowania u dzieci opinii na temat świata medialnego. To właśnie rodzice powinni pomóc swojemu dziecku w wyrobieniu krytycznego stosunku do informacji podawanych w mass mediach. Jeżeli nie potrafią obiektywnie odnosić się do mediów, to dzieci nie będą miały możliwości dostrzeżenia nierealności świata medialnego (Kozłowska, 2006). Beata KrzesińskaŻach uważa, że rodzice powinni wprowadzać dziecko w świat mediów, ponieważ to przede wszystkim na nich ciąży obowiązek wytłumaczenia mu, w jaki sposób należy odpowiedzialnie korzystać ze środków masowego przekazu. Powinni dokonywać selekcji programów i bajek oglądanych przez dziecko, upewniwszy się, że są one dostosowane do jego rozwoju emocjonalnego i psychicznego. Bajka powinna rozwijać wyobraźnię oraz procesy psychiczne dziecka, a także uczyć je czegoś przydatnego w życiu codziennym, nie będąc wyłącznie miłą rozrywką. Media elektroniczne mogą także pomóc rodzicom w wychowaniu dziecka oraz integrować rodzinę, pod warunkiem, że są odpowiednio wykorzystywane i udostępniane dzieciom przez dorosłych. Potrzebne są do tego kompetencje medialne, które rodzice mogą podwyższyć, wzbogacając wiedzę na temat mass mediów, a oznacza to czytanie właściwych książek oraz sprawdzanie wiarygodności informacji w kilku źródłach (Krzesińska-Żach, 2005). 
Urszula Kazubowska pisze bardzo trafnie na temat rodziny i nowoczesnych technologii, twierdząc, że często rodzice mają zbyt mało czasu, który mogą poświęcić swoim dzieciom, ponieważ kieruje nimi żądza pieniędzy i cały czas pracują, aby zapewnić wysoki standard życia swojej rodzinie. Jak pisze dalej, „niestety, te urządzenia nie zastąpią prawdziwej miłości rodzica" (Kazubowska, 2017, s. 178). Tego samego zdania jest Grażyna Gaj, która twierdzi, że „funkcjonowanie współczesnej rodziny w dobie mass mediów jest ogromnym wyzwaniem" (za: Janicka-Olejnik, Klimek, 2016, s. 48), ponieważ bardzo często oboje rodzice są pochłonięci swoją pracą, co ogranicza im czas, który mogą spędzić z dziećmi.

\section{Urządzenia elektroniczne w życiu dziecka}

W dzisiejszych czasach większość dzieci ma dostęp do komputera, laptopa, tabletu czy telefonu komórkowego z Internetem. Urządzenia te są wykorzystywane zarówno do edukacji oraz poszukiwania informacji, jak i do spędzania czasu wolnego podczas grania w gry komputerowe, oglądania bajek oraz komunikowania się przez portale społecznościowe. Jak twierdzi Piotr Gawliczek, „rzeczywistość online nie tylko w dużej mierze wypełnia czas wolny, ale oferuje możliwość kreowania nowego świata, bez wychodzenia z domu" (Gawliczek, 2017, s. 78). Największy wpływ na to, ile dziecko spędza czasu przed urządzeniami elektronicznymi, mają rodzice. To oni powinni wyznaczać im pewne granice czasowe, aby dzieci nie spędzały całych dni z komputerem, tabletem, telewizorem, telefonem.

Do ulubionych zajęć dzieci należy też oglądanie telewizji. Niektórzy rodzice sami często włączają dziecku telewizor, gdy są zmęczeni po pracy i chcą odpocząć, bywają natomiast domy, w których jest on włączony przez cały dzień. A „dziecko, mając na co dzień styczność z non stop włączonym telewizorem, zaczyna go traktować jako nieodłączną część swojego życia” (Przygońska, 2011, s. 129). Oglądanie telewizji przez dłuższy czas jest szkodliwe dla najmłodszych, ponieważ obrazy na ekranie zmieniają się bardzo szybko i mózg dziecka nie potrafi przetworzyć wszystkich informacji, co oddziałuje negatywnie na rozwój funkcji poznawczych dziecka (Fiołka, 2018). Według Agnieszki Gutowskiej-Wyki „programy, bajki, filmy, reklamy są źródłem licznych wrażeń wzrokowo-słuchowych, które mogą obciążać system nerwowy, zmuszając go do nieustannego wysiłku i powodować zmęczenie" (Gutowska-Wyka, 2016, s. 84).

Telewizja dostarcza dzieciom wiele propozycji programowych, z których nie wszystkie są dostosowane do małego widza. Często w programach dla dzieci promowana jest agresja, przemoc, zło. Zdarza się też, że bajka nie uczy niczego - nie ma puenty i morału i jest tylko elementem wypełniającym dzień 
dziecka. Według Michela Desmurgeta „Z ontogenetycznego punktu widzenia czas poświęcony oglądaniu telewizji jest jałowy, całkowicie bezużyteczny. Telewizja niczego nie uczy, nie buduje żadnych powiązań i w ostatecznym rozrachunku nie pobudza żadnych podstawowych umiejętności, które niedojrzały jeszcze mózg musi wykształcić. [...] Mózg nie kształtuje się poprzez obserwację rzeczywistości, ale poprzez oddziaływanie na nią” (za: Dusza, 2013 s. 7). „Bohaterowie w bajkach dla dzieci są ukazywani w walce dobra ze złem, lecz środkiem do zwycięstwa jest zazwyczaj wszechobecna przemoc, sprawność i szybkość. Morał z tych bajek jest taki, że sposobem rozwiązywania sporów jest prawo pięści, a nie, jakby się mogło wydawać, rozmowa. W filmach animowanych bohater często pokazywany jest jako istota wszechwładna, niezniszczalna, posiadająca kilka żyć, posługująca się nie swoim umysłem czy rozsądkiem, lecz bronią i sztukami walki” (Jegier (red.), 2016, s. 115). A przecież programy dla dzieci powinny kształtować wartości i mieć walor edukacyjny. Dlatego ważny jest „selektywny i aktywny dobór programów telewizyjnych, tj. w wyniku świadomie zaplanowanej i odpowiednio ukierunkowanej ich percepcji” (Łobocki, 1994, s. 109).

„Telewizja ma także ogromny wpływ na rozwój psychiczny najmłodszych” (Jegier (red.), 2016, s. 110). Problemem jest też to, że dziecko często bawi się w pokoju, w którym jest włączony telewizor. Rodzice uważają, że nie przeszkadza mu to, co jest nieprawdą. Badania wykazały, że w takich warunkach zaburzona jest spontaniczna aktywność dziecka. Nie może się ono skupić na zabawie, ponieważ co jakiś czas zerka na ekran telewizora. Powoduje to częstszą zmianę zabawek, a co za tym idzie - zabawy są uboższe. Skutkiem tego może być rozdrażnienie i zmęczenie oraz zaburzenia zdolności do skupienia uwagi (Jegier (red.), 2016).

Dzięki portalom społecznościowym można się komunikować z użytkownikami internetu, na całej kuli ziemskiej o każdej porze dnia i nocy. Ta forma komunikacji znacznie różni się od zwyczajnej rozmowy twarzą w twarz z drugim człowiekiem. Gdy wysyłamy komuś wiadomość, nie wiemy, kiedy ta osoba ją odczyta i odpisze. Gdy długo nie odpisuje, nie wiemy, co jest przyczyną - czy brak możliwości odczytania wiadomości, brak czasu, czy niechęć do rozmowy. W rozmowie „na żywo” od razu można zauważyć, że jesteśmy ignorowani przed drugą osobę (Uhls, 2016). W świecie wirtualnym, gdy nie chcemy z kimś rozmawiać, wystarczy rozmówcę zablokować i w ten sposób wręcz usunąć ją z życia, co w realnym świecie jest to niemożliwe (Grudzień, 2017).

Na portalach społecznościowych można rozmawiać z osobami, które się zna w świecie realnym, lub zawierać nowe, wirtualne tylko znajomości. Obecnie jednymi z najpopularniejszych portali społecznościowych są Facebook, Twitter, YouTube, Instagram oraz Snapchat. Dzieci chętnie z nich korzystają. Problemu nie stanowi dla nich nawet to, że konto na Facebooku można założyć do- 
Portale i aplikacje, z których korzystają dzieci we wczesnym wieku szkolnym

\begin{tabular}{|c|c|c|c|c|c|}
\hline & 6 lat & 7 lat & 8 lat & 9 lat & Ogólem \\
\hline Facebook & $13,2 \%$ & $16,3 \%$ & $17,0 \%$ & $22,4 \%$ & $17,4 \%$ \\
\hline Instagram & $17,6 \%$ & $14,1 \%$ & $17,0 \%$ & $15,8 \%$ & $15,9 \%$ \\
\hline Snapchat & $21,6 \%$ & $27,8 \%$ & $29,8 \%$ & $27,7 \%$ & $27,2 \%$ \\
\hline YouTube & $79,6 \%$ & $88,3 \%$ & $91,6 \%$ & $86,2 \%$ & $87,1 \%$ \\
\hline Skype & $15,4 \%$ & $18,1 \%$ & $20,8 \%$ & $28,6 \%$ & $20,9 \%$ \\
\hline Twitter & $9,1 \%$ & $8,9 \%$ & $7,1 \%$ & $11,0 \%$ & $9,0 \%$ \\
\hline WhatsApp & $16,3 \%$ & $19,7 \%$ & $22,2 \%$ & $22,7 \%$ & $20,5 \%$ \\
\hline
\end{tabular}

Źródło: https://www.mcpu.krakow.pl/sites/default/files/korzystanie_z_urzadzen_elektronicznych_ oraz_z_internetu_przez_dzieci_i_m.pdf (dostęp 17 IV 2019)

piero od trzynastego roku życia - fałszują po prostu rok swojego urodzenia. Podobne założenie ma aplikacja zwana Snapchat. Służy ona do szybkiego wysyłania zdjęć i filmików, które są widoczne jedynie przez 10 sekund, następnie są usuwane i nie można ich ponownie zobaczyć. Aplikacja ta również jest nieodpowiednia dla dzieci poniżej trzynastego roku życia, a dzieciom w wieku 13-17 lat zezwala się na założenie konta jedynie za zgodą rodzica. Większość użytkowników tej aplikacji ma poniżej 17 lat. Niestety, mało które dziecko i rodzic znają regulaminy, większość z nich instaluje aplikacje na swoich urządzeniach elektronicznych i korzysta $z$ nich bez przeczytania regulaminu.

Istnieje więc wiele aplikacji i portali społecznościowych, które są ogólnodostępne dla dzieci, co nie oznacza, że są one dostosowane do wieku dzieci.

Tabela na s. 24 przedstawia procentowy udział korzystania z poszczególnych aplikacji przez dzieci w wieku 6-9 lat.

Najwięcej ankietowanych dzieci korzysta z YouTube (87\%). Na drugim miejscu znajduje się Snapchat, z którego korzysta 27\% dzieci. Widać więc wyraźną różnicę pomiędzy udziałem procentowym dzieci, które korzystają z YouTube, oraz ze Snapchata - wynosi ona aż 61\%. Podobna liczba dzieci korzysta ze Skype'a oraz z WhatsAppa (21\% wszystkich ankietowanych). Stosunkowo mały procent dzieci w wieku 6-9 lat korzysta $z$ Instagrama (16\%) oraz z Facebooka (17\%), co może wydawać się zaskakujące. Najmniej popularnym portalem wśród tych dzieci jest Twitter, z którego korzysta jedynie 9\%.

Według Anety Jegier „rodzina jest pierwszą podstawową grupą społeczną, w której dziecko uczy się zarządzać czasem wolnym" (Jegier (red.), 2016, s. 14). Rodzice powinni od najmłodszych lat uczyć dziecko, jak powinno gospodarować wolnym czasem. Jegier uważa także, że rodzice, którzy wiedzą, jak prawidłowo organizować czas wolny dziecka, dają mu wzór, jak ma go planować w dorosłym życiu. Tego samego zdania są Martyna Cembrzyńska i Emilia Pisarzowska-Izbińska, które piszą: „[...] sposób spędzania czasu wolnego, prefero- 
wane aktywności przez rodziców oraz ich ulubione formy rozrywki w danej rodzinie mają wpływ na to, jak dzieci będą kreowały swój czas wolny w życiu dorosłym" (Cembrzyńska, Pisarzowska-Izbińska, 2016, s. 206). Tak więc dziecko uczy się od swojej rodziny, w jaki sposób można spędzać wolny czas. Istotne jest, aby rodzice poświęcali swoim dzieciom jak najwięcej czasu, ponieważ to ich do siebie zbliża. Każde dziecko lubi, jak rodzice poświęcają mu uwagę, i są przez pewien czas tylko do jego dyspozycji. Niestety, nie wszyscy rodzice chcą poświęcać swój czas tylko dziecku. Niektórzy z nich twierdzą, że „czas spędzony $\mathrm{z}$ dzieckiem jest takim czasem straconym, bo przecież $\mathrm{w}$ tym czasie są bezproduktywni, a tyle można byłoby zrobić” (Jegier (red.), 2016, s. 15).

\section{Badania własne}

Przedmiotem badań był czas wolny dzieci w wieku wczesnoszkolnym, a głównym celem - rozpoznanie i opis czasu wolnego, w tym spędzanego $z$ wykorzystaniem urządzeń elektronicznych, oraz zaangażowanie rodziców w organizację czasu wolnego dzieci. Głównym problemem badawczym było pytanie, jak czas poświęcany dzieciom przez rodziców warunkuje aktywność medialną dzieci.

Skupiono się na następujących problemach szczegółowych:

- $\mathrm{Z}$ jakich urządzeń elektronicznych korzystają dzieci najczęściej?

- W jakim celu najczęściej dzieci korzystają z urządzeń elektronicznych i jakie aktywności wykonują przy ich użyciu?

- Ile średnio dziennie czasu dzieci spędzają z urządzeniami elektronicznymi?

- Jakie formy kontroli dziecka stosują rodzice podczas korzystania z Internetu i jakie reguły ustalają odnośnie do korzystania z urządzeń elektronicznych?

- Jakie aktywności wykonują rodzice w czasie korzystania przez dzieci z urządzeń elektronicznych?

- Ile średnio dziennie czasu rodzice poświęcają dzieciom i jakie formy spędzania czasu wolnego preferują?

W badaniach zastosowano metodę sondażu diagnostycznego, wykorzystano technikę ankiety, narzędziem był natomiast kwestionariusz ankiety.

W badaniach dotyczących mediów elektronicznych oraz czasu wolnego dziecka wzięli udział rodzice uczniów klas drugich, uczęszczających do szkół w Krakowie, Gołaczewach, Chełmie, Zarzeczu oraz Dłużcu. Kwestionariusze ankiet zostały rozdane uczniom, którzy przekazali je rodzicom za zgodą dyrektorów placówek. W szkole w Krakowie rozdano w klasach drugich 73 kwestionariusze ankiety, odebrano natomiast 35 wypełnionych przez rodziców. W pozostałych szkołach, czyli tych znajdujących się na wsi, rozdano w sumie 60 an- 
kiet i odebrano również 35 uzupełnionych przez rodziców. Rozdano więc łącznie 133 kwestionariusze ankiety, z czego odebrano 70 wypełnionych, co daje $53 \%$. Oznacza to, że aż $47 \%$ rodziców nie wzięło udziału w przeprowadzonym badaniu.

Jeżeli chodzi o miejsce zamieszkania, to połowa ankietowanych mieszka w mieście powyżej 30 tys. mieszkańców, a druga połowa na wsi, niemniej porównując odpowiedzi na poszczególne pytania nie zauważono znaczących różnic pomiędzy osobami zamieszkującymi wieś i miasto. Oznacza to, że odpowiedzi były zbliżone do siebie, zostały więc przedstawione zbiorczo. Wyjątkiem było pytanie dotyczące zajęć pozalekcyjnych, na które uczęszcza dziecko.

Z przeprowadzonych badań wynika, że większość rodziców stara się dbać o to, aby ich dzieci nie spędzały zbyt dużo czasu z urządzeniami elektronicznymi oraz kontroluje ich aktywność w internecie. Przeważająca liczba dzieci korzysta $\mathrm{z}$ elektroniki $\mathrm{w}$ przedziale czasowym 30-120 minut. Dokładniej: $39 \%$ dzieci spędza średnio w ciągu dnia 30-60 minut przed komputerem/telewizorem, a 36\% dzieci korzysta z tych sprzętów przez 60-120 minut dziennie. Na podstawie odpowiedzi z kwestionariusza ankiety można twierdzić, że większość rodziców ma ustalony dzienny limit czasu, jaki dzieci mogą spędzać z urządzeniami elektronicznymi, oraz reguły korzystania z tych sprzętów. Przeważnie limit ten wynosi do 60 minut dziennie. Preferuje go 31\% badanych, ale także $31 \%$ dzieci nie ma żadnego ustalonego limitu. Pozostałe dzieci mają ustalony inny limit czasu korzystania ze sprzętów elektronicznych. Jeżeli chodzi o najczęstsze zasady, to należy do nich przede wszystkim korzystanie z tego typu urządzeń po odrobieniu wszystkich zadań domowych i wypełnieniu innych obowiązków (39\%) oraz po uzyskaniu pozwolenia od rodziców (37\%). 7\% rodziców nie ma ustalonych $\mathrm{z}$ dzieckiem żadnych reguł. 71\% rodziców czynnie kontroluje aktywność dziecka w internecie, 23\% ma zaufanie do dziecka, a $6 \%$ nie kontroluje czynności podejmowanych przez dziecko w sieci. $91 \%$ dorosłych deklaruje odbycie rozmowy $\mathrm{z}$ dzieckiem na temat niebezpieczeństw $\mathrm{w}$ internecie, lecz $9 \%$ ankietowanych rodziców takiej rozmowy nie przeprowadziło.

W kwestionariuszu ankiety znalazły się pytania dotyczące czasu, jaki rodzice średnio spędzają $z$ dzieckiem. Większość rodziców w tygodniu pracuje, a po pracy musi albo zrobić zakupy, opłacić rachunki, ugotować obiad, albo po prostu odpocząć. Dzieci chodzą do szkoły, a po szkole często uczęszczają na zajęcia dodatkowe, aby rozwijać swoje zdolności lub pasje. Dlatego pytanie to zostało rozdzielone na dwie części: pierwsza dotyczyła czasu, który rodzice średnio poświęcają swojemu dziecku w tygodniu, tj. od poniedziałku do piątku; druga odnosiła się do weekendu.

Najwięcej rodziców w tygodniu (tj. od poniedziałku do piątku) poświęca swojemu dziecku ponad dwie godziny. Takiej odpowiedzi udzieliło 30 osób (43\%). Druga najliczniejsza grupa twierdziła, że poświęca dziecku 1-2 godziny 
dziennie ( $27 \%$ - 19 osób). 19\% ankietowanych (13 osób) przyznaje, że znajduje dla dziecka w tygodniu 30-60 minut dziennie, jedna osoba zaznaczyła, że jej czas dla dziecka wynosi 15-30 minut dziennie, co może się wydawać mało, ponieważ tyle trwa przeczytanie bajki na dobranoc. Aż $10 \%$ ankietowanych (7 osób) nie potrafiło ocenić, ile czasu poświęcają swojemu dziecku od poniedziałku do piątku. Można to interpretować dwojako: rodzice i dzieci mają różne rozkłady dnia i ich czas jest uwarunkowany dniem tygodnia lub czują niechęć do udzielenia odpowiedzi na to pytanie.

Kolejne pytanie dotyczyło tego, ile rodzice poświęcają czasu swojemu dziecku w weekendy. Zdecydowana większość ankietowanych rodziców w weekend spędza ze swoim dzieckiem ponad trzy godziny. Odpowiedź tę zaznaczyło 45 z 70 osób (64\%). Druga pod względem liczebności głosów grupa poświęca dziecku w weekend 2-3 godziny (12 osób, czyli 17\% badanych). Kolejna spędza z dzieckiem 1-2 godziny, co zadeklarowało 7 ankietowanych (10\%). Do spędzania $\mathrm{z}$ dzieckiem $\mathrm{w}$ weekend tylko 30-60 minut przyznała się 1 osoba (1\%). Odpowiedź „trudno stwierdzić” wybrało 12 rodziców (17\%). Przyczyny wybrania tej odpowiedzi mogą być identyczne jak przy poprzednim omówionym pytaniu.

Wiedząc już, ile czasu średnio rodzice poświęcają swoim dzieciom w tygodniu, a ile w weekend, należy powiedzieć, jakie preferują formy spędzania czasu wolnego z dzieckiem. To, w jaki sposób rodzice spędzają czas z dzieckiem, jest ważne dla wytworzenia się więzi rodzinnych. Jeżeli rodzina będzie się ze sobą widywać jedynie przed telewizorem, to nie będzie miała okazji do wspólnych rozmów. Najwięcej rodziców w wolnym czasie zabiera dzieci na spacery lub wycieczki. Odpowiedź tę zaznaczyło aż 55 z 70 ankietowanych (79\%). Drugą najliczniej wybieraną odpowiedzią jest aktywność sportowa. Preferuje ją $47 \%$ badanych osób. Zaraz za nią plasują się cztery odpowiedzi, które również rodzice bardzo często zaznaczali: gry planszowe (40\%), czytanie książek (37\%), wyjścia na plac zabaw (34\%), wspólne oglądanie bajek/filmów (31\%). Jeżeli chodzi wyjście do kina lub teatru, to formę tę preferuje $27 \%$ ankietowanych rodziców, a wyjście na zakupy $23 \%$ osób. Najmniej rodziców w czasie wolnym bawi się z dzieckiem jego zabawkami (17\%) oraz wykonuje prace plastyczne, takie jak rysowanie, malowanie, lepienie z plasteliny itp. (10\%). Odpowiedź „inne” zaznaczyło 6\%, czyli 4 rodziców. Dwoje z nich w wolnym czasie gotuje z dzieckiem, a pozostałych dwoje odwiedza dziadków oraz rozmawia $\mathrm{z}$ dzieckiem.

Według ankietowanych uczestnictwo dzieci w zajęciach dodatkowych jest bardziej popularne w mieście niż na wsi. W lekcjach językowych bierze udział 24 z 35 dzieci miejskich (69\%), podczas gdy na wsi w tych zajęciach uczestniczy trzy razy mniej dzieci ( 8 z $35-23 \%)$. Na zajęcia sportowe chodzi $63 \%$ dzieci mieszkających w mieście, a na wsi $-37 \%$ dzieci. $46 \%$ rodziców opłaca swoim dzieciom zajęcia taneczne, a na wsi w tych zajęciach bierze udział $9 \%$. Jeżeli 
chodzi o zajęcia muzyczne i plastyczne, to zapisanych jest na nie odpowiednio $23 \%$ i $26 \%$ dzieci w mieście; na wsi - 14\% i 3\% dzieci. Natomiast na zajęcia akrobatyczne chodzą jedynie dzieci ze wsi (6\%). Żadne z dzieci ankietowanych rodziców mieszkających $\mathrm{w}$ mieście nie bierze udziału w tego typu zajęciach. Co do odpowiedzi „inne”, to $26 \%$ rodziców miejskich wybrało tę odpowiedzieć i dopisało, że ich dzieci chodzą na następujące zajęcia dodatkowe: robotyka, szachy, Uniwersytet Dzieci, dwoje dzieci na kółko matematyczne, dwoje na szycie i dwoje na basen. Tę odpowiedź wybrał tylko jednej rodzic mieszkający na wsi (3\%) i dopisał, że jego dziecko chodzi na szachy. Aż 37\% (13) dzieci wiejskich nie bierze udziału w żadnych zajęciach dodatkowych, podczas gdy w mieście jest tylko jedno dziecko, które nie uczęszcza na żadne zajęcia (3\%). Widoczne są znaczne różnice w liczbie dzieci wiejskich i miejskich uczęszczających na określone zajęcia dodatkowe. Przewaga rodziców mieszkających ze swoimi dziećmi w mieście, którzy posyłają dzieci na zajęcia dodatkowe, może wynikać $\mathrm{z}$ ich lepszej sytuacji materialnej w porównaniu z rodzicami mieszkających na wsi. Przyczyną może też być to, że rodzice w mieście więcej pracują i w tym czasie zapewniają opiekę swoim pociechom przez zajęcia dodatkowe. Ważnym aspektem jest też to, że w dużym mieście jest większy wybór zajęć dodatkowych i miejsc ich odbywania się niż na wsi.

Najwięcej dzieci bierze udział w zajęciach sportowych $-50 \%$ dzieci ankietowanych rodziców zaznaczyło tę odpowiedź. Zaraz za nimi są lekcje językowe, na które chodzi $46 \%$ dzieci. Na zajęcia taneczne uczęszcza $20 \%$ dzieci, na muzyczne $-19 \%$, na plastyczne - 14\%, na akrobatyczne - 3\% wszystkich dzieci. $14 \%$ dzieci chodzi na inne zajęcia niż wymienione, a $20 \% \mathrm{z}$ nich nie uczęszcza na żadne zajęcia dodatkowe.

Podsumowując: większość rodziców spędza ze swoim dzieckiem średnio ponad dwie godziny dziennie od poniedziałku do piątku, w weekend natomiast ponad trzy godziny. W tym czasie większość rodziców najczęściej zabiera dzieci na spacer i na wycieczki lub uprawia wspólnie jakiś sport, gra w gry planszowe, czyta wspólnie książki, wychodzi na plac zabaw oraz ogląda bajki. Z badań wynika również, że uczęszczanie dzieci na zajęcia dodatkowe jest bardziej popularne w mieście niż na wsi, lecz na obu badanych obszarach najwięcej dzieci chodzi na zajęcia językowe i sportowe.

\section{Zakończenie}

Z przeprowadzonych badań można wysunąć pewne wnioski. Najważniejszy: zdecydowana większość uczniów klasy drugiej szkoły podstawowej posiada własne urządzenia elektroniczne. Jest to spowodowane powszechnością sprzętów mobilnych. Rodzice powinni jednak dbać o to, aby dzieci nie spędzały zbyt 
dużo czasu na korzystaniu z nich. Drugoklasista nie powinien też codziennie korzystać z internetu, a większość swojego czasu wolnego poświęcać zabawie ruchowej lub twórczej.

Niestety, nie wszyscy rodzice ustalają z dzieckiem limit czasu na korzystanie z urządzeń elektronicznych oraz reguły korzystania z nich. Dziecko powinno wiedzieć kiedy, w jakich sytuacjach i ile czasu może spędzić przy komputerze czy telewizorze. Pozwoli to na ustalenie w miarę regularnego trybu dnia dziecka. Także nie wszyscy rodzice rozmawiali ze swoimi dziećmi na temat zagrożeń w internecie. Obowiązkiem każdego rodzica powinno być przeprowadzenie takiej rozmowy. W szkole powinny być organizowane prelekcje na temat bezpiecznego korzystania $z$ internetu. Każde dziecko musi mieć świadomość tego, z jakimi niebezpieczeństwami może się spotkać w sieci, jak postępować, aby ich unikać i co zrobić w sytuacji jakiegokolwiek zagrożenia. Rodzice winni pamiętać, że sukcesem do racjonalnego korzystania przez dzieci z urządzeń elektronicznych teraz i w przyszłości jest przykład dawany przez nich samych.

\section{Bibliografia}

Cembrzyńska, M., Pisarzowska-Izbińska, E. (2016). Perspektywa postrzegania czasu a postawa wobec spędzania czasu wolnego w gronie rodzinnym. W: V. Tanaś, W. Welskop (red.), Kultura czasu wolnego we wspótczesnym świecie. Wyd. Naukowe Wyższej Szkoły Biznesu i Nauk o Zdrowiu, Łódź, s. 205-213, https://www.medyk.edu.pl/wgrane-pliki/kultura_czasu_wolnego_we_wspolczesnym_swiecie_red._v.tanas_w.welskop.pdf (dostęp 17 V 2019).

Czerepaniak-Walczak, M. (1997). Gdy po nauce mamy wolny czas... Szczecin: Wyda. „PoNaD”.

Dusza, B. (2013). Telewizja w codzienności dziecka (raport $z$ badań), http://www.ktime.up.krakow.pl/ symp2013/referaty_2013_10/dusza.pdf (dostęp 12 II 2019).

Fiołka, H. (2018). Znaczenie mediów we wczesnej edukacji. „Pedagogika Przedszkolna i Wczesnoszkolna", 2 (12), s. 99-108.

Gawliczek, P., (2017). Fak wykorzystać nowoczesne media w rodzinie, szkole i na uczelni? Rekomendacje $i$ doświadczenia Kujawskiej Szkoły Wyższej we Wtoctawku z użytkowania platformy e-learningowej LMS ILIAS. W: R. Brzezińska (red.), Rodzina wobec globalnej zmiany cywilizacyjno-medialnej. Włocławek: Kujawska Szkoła Wyższa, s. 77-88.

Grudzień, A. (2017). Internet jako uzależnienie od nowoczesności. w: Brzezińska R. (red.) Rodzina wobec globalnej zmiany cywilizacyjno-medialnej., W: R. Brzezińska (red.), Rodzina wobec globalnej zmiany cywilizacyjno-medialnej. Włocławek: Kujawska Szkoła Wyższa, Włocławek: Kujawska Szkoła Wyższa, s. 59-76.

Gutowska-Wyka, A., (2016). Niewtaściwe spędzanie czasu wolnego jako przyczyna nadwagi i otytości u dzieci i młodzieży. W: V. Tanaś, W. Welskop (red.), Kultura czasu wolnego we wspótczesnym świecie. Wyd. Naukowe Wyższej Szkoły Biznesu i Nauk o Zdrowiu, Łódź, s. 81-89, https://www. medyk.edu.pl/wgrane-pliki/kultura_czasu_wolnego_we_wspolczesnym_swiecie_red._v.tanas_w. welskop.pdf (dostęp 17 V 2019).

Janicka-Olejnik, E., Klimek, K. (2016). Dzieci i młodzież w świecie technologii cyfrowej. Łódź: Wyd. Akademii Humanistyczno-Ekonomicznej.

Jegier, A. (red.) (2016). Czas wolny małych dzieci w świecie realnym i wirtualnym. Warszawa: Difin. 
Kazubowska, U., (2017). Rodzina jako przestrzeń edukacji ku/dla bezpieczeństwa dzieci i młodzieży w cyberprzestrzeni. Rzeczywistość i wyzwania. W: M. Górka, (red.), Cyberbezpieczeństwo dzieci i młodziezy. Realny $i$ wirtualny problem polityki bezpieczeństwa. Warszawa: Difin, s. 162-191.

Kozłowska, A. (2006). Oddziaływanie mass mediów. Warszawa: SGH.

Krzesińska-Żach, B., (2005). Edukacja medialna dziecka w rodzinie - wybrane aspekty. w: J. Izdebska, T. Sosnowski, Dziecko i media elektroniczne - nowy wymiar dziecinstwa, 1. Białystok: Trans Humana, s. 54-59.

Łobocki, M. (1994). Organizowanie pracy wychowawczej z dziećmi i młodzieża. Warszawa: PWN.

Martyka, A. (2012). Czas wolny dzieci we wspótczesnych polskich miastach. Wprowadzenie do poszukiwań optymalnych rozwiazań przestrzennych, https://suw.biblos.pk.edu.pl/resources/i3/i6/i9/i0/i9/ r36909/MartykaA_CzasWolny.pdf (dostęp 13 IV 2019).

Przygońska, E. (2011). Fak dzieciom i młodzieży rodzina powinna organizować czas wolny?. „Pedagogika Rodziny”, 1/3/4, s. 121-131. http://bazhum.muzhp.pl/media//files/Pedagogika_Rodziny/Pedagogika_Rodziny-r2011-t1-n3_4/Pedagogika_Rodziny-r2011-t1-n3_4-s121-132/Pedagogika_ Rodziny-r2011-t1-n3_4-s121-132.pdf (dostęp $2 \overline{8}$ V 2019).

Uhls, Y. T. (2016). Cyfrowi rodzice. Dzieci w sieci. Fak być czujnym, a nie przeczulonym. Przeł. I. Grzegrzółka. Kraków: IUVI. 